\title{
A megváltozott családok hatása a gyermekekre
}

\author{
M. Nádasi Mária \\ Eötvös Loránd, Pedagódiai és Pszichológiai Kar
}

\begin{abstract}
A családdal való együttmüködés az iskola megkerülhetetlen feladata. Ez azt feltételezi, hogy a pedagógus mindenkor tájékozott azzal kapcsolatban, hogy aktuálisan mi jellemző a folyamatosan változó családokra, amely tudására támaszkodva megfelelöen tud reagálni tanítványai családi hátterének a diákok taníthatóságában, nevelhetőségében megjelenő következményeire. Az írás számba veszi a családok legfontosabb megismerési szempontjait, és pillanatképet készít arról, hogy jelenleg milyen tudásra támaszkodhatnak a pedagógusok a konkrét családok megismerésével kapcsolatban, milyen ma éppen a „változó család”.
\end{abstract}

Kulcsszavak: családértelmezések, értékek a családban, családszerkezetek, krízisek a családban, a laikus pedagógiai nézetek szerepe a családi nevelésben

\section{A család értelmezése}

A családról gondolkodva úgy tizenöt évvel ezelött még természetesnek tűnt egy olyan hagyományos alapértelmezés, amely szerint a család a társadalomnak az a legkisebb szociális egysége, amelyben házasságban élő férfi és nő együtt él/nek vér szerinti közös gyermekükkel/gyermekeikkel. És természetesen hozzá lehetett tenni, hogy persze, ettöl eltérések azért vannak. Később megengedőbben, a valóság ismeretében alternatív család változatokról kezdtünk beszélni. (A pedagógiában ezek közül leggyakrabban talán a növekvő válási számok miatt a csonkacsaládról mint sajátos nevelési körülményeket teremtő közegröl volt szó. Ma ezt a kifejezést pejoratív jelentése miatt már nem is használjuk.)

Jelenleg ez a család értelmezés már szüknek bizonyul, hiszen lehetséges, hogy az eltérő változatok ma már a többséget képviselik. Mert milyen, a napi életből ismert formációk maradnak ki ebből a hagyományos értelmezésből? Az a változat, amikor

- a gyermeket örökbe fogadják;

- a saját gyermeket és az örökbe fogadottat együtt nevelik;

- a saját gyermek ismeretlen donortól származik;

- az együtt nevelt gyermekek részben az egyik, részben a másik, részben mindkét szülötöl származnak;

- válás vagy árvaság vagy a szülő által vállalt szingli életforma miatt egy szülő neveli a gyermeket (már nem csonka családról, hanem egyszülős családról beszélünk!);

- árvaság vagy a szülök nevelésre alkalmatlan életmódja miatt más családtag ( $p l$. nagyszülö, hivatalos gyám) neveli a gyermeket;

- a család felnőtt tagjai csak alkalmilag élnek együtt;

- a család felnőtt tagjai homoszexuális kapcsolatban élnek;

- a kulturális sajátosságok következtében a hazai alapértelmezéstől eltérő más együttélési megoldást, és sajátos nevelési körülményeket, módszereket tartanak természetesnek.

Azt azonban nem lehet említés nélkül hagyni, miszerint még mindig nem ritka az a vélemény sem, hogy ez a sokféleség nem fér össze a család értelmezésével, hogy mindez inkább a család válságát jelzi, a család felmorzsolódását jelenti.

Ha azonban a realitás, az élet és kitüntetetten a pedagógus professzió felöl közelítünk a család értelmezéséhez, azt mondhatjuk, hogy a család, mint a társadalom 
alapegysége, sokféle módon jelenik meg. Mindegyik változatában bonyolult, s bár egyedileg is állandóan módosuló rendszer, amelyet a gyermekek mégis állandónak élnek meg, mert a biztonságot jelenti számukra (még akkor is, ha - mint oly gyakran - a „családegyesítés” rendre csak az ő fejükben, érzelmeikben, vágyaikban, fantáziájukban folyik).

A fentieket mérlegelve megoldás lehet a család ernyő-fogalomként való értelmezése. Eszerint tudomásul vesszük, hogy a család megjelenési formája változatos, de ha teljesíti a család funkcióit, akkor tekinthetjük családnak.

De melyek ezek a funkciók? A hazai szakirodalomban hagyományosan a következőket szoktuk említeni: a család érzelmi támaszt és gazdasági biztonságot nyújt tagjainak; a regenerálódás színtere; a közös kulturális identitás alapja; reprodukciós funkció, a gyermek szocializálódásának első közege - és ezt általánosnak feltételezzük.

A valóság ismeretében kimondhatjuk, hogy bonyolultságuk, a társadalmi, gazdasági körülményektöl sok szálon való függésük miatt e funkciókat nem minden család, nem mindig tudja teljesíteni. Még abban is lehet különbség, hogy a társadalmi-kulturális hagyományok miatt melyik családban mikor, mire helyezik a hangsúlyt. (2003-ban nagymintás, reprezentatív összehasonlító pedagógiai vizsgálat alapján levonhattuk például a következtetést (Bábosik, Brunner és Nádasi, 2005): a család müködésében legfontosabbnak tartott funkció mind a magyar fiatal felnőttek (19-29 évesek), mind a fiatal felnőtt gyermekkel rendelkező magyar lakosság körében a gazdasági biztonság megteremtése s konkrétan az idős szülök gyámolítása. A német (thüringiai) minta szerint a fiatalok a családdal kapcsolatos legfontosabb funkciónak azt tartják, hogy a család emocionális támaszt ad tagjai számára, a szülői minta szerint pedig a gyerekek anyagi támogatása a legfontosabb.)

A funkciók jelentőségének és megvalósításának családokhoz kapcsolható különbözőségét tudomásulvéve elfogadhatónak, indokolhatónak látszik a családdal kapcsolatos kritériumoknak a legfontosabbra, kikerülhetetlenre csökkentése. Ez a természetes reprodukciós, szocializáló funkció. A továbbiakban ezért Bönisch és Lenz család-értelmezését fogadjuk el, amely szerint a család olyan generációk közötti kapcsolat, amely kapcsolat szülö-gyermek viszonyként írható le (Bönisch és Lenz, 1997).

Ebbe a tág értelmezésbe belefér a szimbolikus család is. Mert, ahogy a kutatások érdekesen és meggyőzően felmutatják, életünkben fontos szerepet játszhat az ún. szimbolikus család, amelybe mindenki beletartozik, akit akár közösen, akár egyénileg elér az emlékezet, a képzelet. A szimbolikus család narratívákban, személytől, időtől, szituációtól függően is változó narratívákban jelenik meg - lehetővé téve a családok, a családtagok, így a gyermekek számára is a párhuzamos többféleséget, a különböző szocializációs mintákkal való azonosulást, a szabadság (napi tapasztalatoktól független) megélését (Boreczky, 2004.).

\section{A pedagógusok különböző, konkrét családokkal találkoznak}

A napi intézményes pedagógiai munkában a családnak nagy szerepe van azáltal, hogy az óvoda, az iskola mintegy társul a családhoz a gyerekek nevelésében. A gyerekek a nevelési intézményekbe az elsődleges szocializációs közösségből érkezve, oda tartozva jelennek meg. Ebben a helyzetben megjelenik a családok és az intézmények, a szülők és a pedagógusok együttmüködésének szükségessége és kényszere. Ebben a kapcsolatban a család képviseli a folytonosságot, a pedagógusok a szakaszosságot. Ezért általában nem a család elméleti értelmezése szokott a téma lenni a pedagógusok beszélgetéseiben, a szülök között, hanem a különböző családok, mint nevelési közegek 
hatása, folytonosan változó hatása a gyermekekre, s ennek következtében a pedagógusok feladatainak változása, vagyis a pedagógusok és a konkrét családokkal való találkozás milyensége. Ebben az összefüggésben az egyes családok és az intézmények, pedagógusok konkrét sajátosságai, összeillésük vagy eltéréseik a meghatározóak.

Összeillés esetén - szerencsés esetben, ha a nevelési törekvések a gyermekek szükségleteivel összhangban vannak - a pedagógiai hatékonyság erőteljes és pozitív lehet. Eltérés esetén, különböző - pedagógiailag megkérdőjelezhető helyzetek - alakulhatnak ki. Például: a család segít a gyermeknek értelmezni az iskolai élményeket; az iskola lemond a gyermek neveléséről, oktatásáról, hivatkozva a család szintjére, ellentétes törekvéseire, közönyére stb.

Ezt a komplex kérdéskört leszűkítve a továbbiakban csak azokra a családi jellemzőkre utalunk, amelyek jelenleg a pedagógusok számára általában vagy egy részük számára mindenképpen szokatlanként jelennek meg, amelyekkel saját életükben korábban valószínüleg nem vagy másképp találkoztak.

A pedagógusok részéről a megszokottól, ismerttől való eltérő müködés miatt gyakran fogalmazódik meg elégedetlenség, kritika általában a családokkal szemben. Ezzel összefüggésben kiindulásul két dolgot mindenképpen érdemes figyelembe venni. Egyrészt a család hatása és a gyermek intézményes „beválása” (nevelhetősége, oktathatósága) között kizárólagos és közvetlen kapcsolatot feltételezni leegyszerüsítő, behaviorista szemléletmód lenne, még az iskola és család összeillése esetén is. A gyerekek nem a családi hatások passzívan elszenvedett, kizárólagos lenyomatai. A döntő folyamatok a családi hatások mellett az intézményes nevelés által is (és természetesen az adottságok, a média és más hatások, tevékenységek által is) befolyásolt „fekete dobozban” zajlanak. A gyermeki psziché valamennyi hatást filterként szüri meg. Másrészt a pedagógusok nem általában a családokkal kerülnek kapcsolatba, hanem konkrét családokkal.

A továbbiakban arról gondolkodunk, hogy melyek a családok közötti különbségek pedagógusok által is akceptálandó/akceptálható legfontosabb forrásai. E források közül a következőket emeljük ki:

- a családok által képviselt értékek különbözők;

- a diákok eltérő szerkezetű családokból érkeznek;

- a családok élethelyzete az éppen aktuális krízisek miatt jelentősen különbözhet egymástól;

- a családtagok egészségi állapota alapvetően meghatározza a gyermekek életminőségét;

- a családok társadalmi, gazdasági helyzete nagy eltérést mutathat;

- a család valláshoz való kapcsolódása befolyásolhatja az iskola elvárásaihoz való viszonyulást;

- a család nemzetiségi, etnikai hovatartozása sajátos nevelési szokásokat alapozhat meg;

- a családokban megjelenő laikus pedagógiai nézetek meghatározzák a családi nevelés légkörét, sajátosságait.

\section{A család által képviselt értékek különbözők}

Kiinduló tételként kezelhetjük, hogy a családok élete mindig is értékek (preferált eszmények, morális nézetek, magatartásmódok, javak, körülmények) mentén szerveződött, bár ezekkel az értékekkel a családok nem feltétlenül voltak/vannak tisztában. A különbségek a családok által (tudatosan vagy nem tudatosan) preferált értékek tartalmában vannak, amely értékek az életmódbeli, a társadalmi-politikai változásokra érzékenyen reagálnak. (Leglassabban talán a morális értékek változnak.) 
A szociológiai értékkutatások korábban már kimutatták, hogy a magyar társadalomban a családok nagymértékben különböztek abban, hogy milyen értékeket preferáltak, bár a társadalmi ideológia az egységességet sugallta, sőt - nehezebb időkről lévén szó - kifejezetten elvárta (Hankiss, 1983).

A pedagógiai kutatások szerint nem kevésbé színes a helyzet abban a tekintetben sem, hogy a családok (szülök, gyermekek), illetve a pedagógusok mit tekintenek értéknek a pedagógiailag értékelhető közegek müködésében, mit preferálnak egymás müködésében. Ezek az értékek elvárásokként, meglétük esetén elismerésként, hiányukat tapasztalva, feltételezve kritikaként jelennek meg.

2012-ben általános iskolai tanulók és szüleik körében végzett (a 2002. évi vizsgálat szempontjait bennfoglaló, de új elemeket is tartalmazó) reprezentatív vizsgálatunkban megállapíthattuk, hogy az általános iskolás diákok szüleinek elvárásaiban egyaránt találkozunk az állandósággal és a változó körülmények miatt megjelenő új elemekkel. (Hunyady és M. Nádasi, 2014) Így tíz éves távlatban tovább erősödött az iskola eredményességével kapcsolatos elvárás (továbbtanulásra felkészítés), mint állandó elem, viszont új elemként jelent meg az iskolai fizikai biztonság igénye. A vizsgálat időbeli körülményeit tekintve ezzel összhangban azt is megállapíthattuk, hogy értékek szintjén a családokat tekintve csak lassú változásra lehet számítani, a szülők értékeit nem annyira a divatos társadalmi jelszavak, mint inkább a gyerekek iránt érzett felelősség, szeretet, a saját iskolai tapasztalatok határozzák meg.

Ugyanebben a vizsgálatban megpróbáltuk azt is felderíteni, hogy a diákok számára mi jelenti az értéket az iskolához kapcsolódóan. A diákok az önállóságot, a nagyobb személyes figyelmet, a társadalmi nemükböl eredő különbségek figyelembevételét várják el, tekintik értéknek az iskoláról gondolkodva.

Kutatásunkban a szülök iskolával kapcsolatos értékeit saját gyerekeik igényeivel hasonlítottuk össze, megállapíthattuk, hogy családon belül valószínűleg sem egybeesés, sem ellentmondás nincs az értékek között: a szülők és a gyerekek helyzetükből adódóan mást emelnek ki értékként a pedagógiai folyamatra vonatkozóan. A pedagógiai értékek a szülők esetében szerep-, a gyermekek esetében szükségletspecifikusak.

A családot illetően nincsenek örök, stabil értékek. A családok értékei a családtagok szükségletei, élethelyzete alapján alakulnak ki, s az együttélés során sajátos, egyedi egyveleget képeznek. Ezekkel találkoznak a pedagógusok.

\section{Az eltérő családi struktúra}

Ahonnan a gyerek érkezik, szerkezete szerint lehet (ha csak a leggyakoribb és legegyszerübb formációkat tekintjük):

- nukleáris család - szülők és gyermekek élnek együtt;

- egyszülős család - válás, haláleset, a szingli életmód (önkéntes vagy kényszerü vállalása) miatt;

- mozaikcsalád - újraházasodás eredményeként;

- nagycsalád - legalább három generáció együttélése esetén.

A multilokális család (Bertram, 1997) esetében pedig már a közös háztartás sem jellemző a családra.

A családszerkezet többféleképpen is kihathat arra, hogy milyen iskolás lesz a gyerek. Ha a hagyományos struktúrának megfelelően az apa és az anya is tagja a családnak, a gyereknek módja van a világos szerepek, minták megismerésére. Ha a családban több gyerek van, a testvérsorban elfoglalt helyzetétöl függően tanulhat meg az iskolában is megjelenő viszonyulási módokat. Ha különböző generációk élnek együtt, lehetőség van a különböző értékrendek megismerésére, ütköztetésére. Egyszülős családban ta- 
pasztalatokat szerezhet a gyermek arról, hogy a napi életvezetés milyen szerepkonfliktusokhoz vezet, és ez milyen következményekkel járhat a vele élő szülőt illetően.

Külön kérdés lehetne, hogy mit jelent, jelent-e valamit a gyerek számára a nem-házasság körülményeibe való beleszületés, illetve ha a családszerkezet az óvodás, iskolás évek alatt változik. Friss statisztikai adat, hogy jelenleg nálunk minden negyedik gyerek nem-házasságban élő szülőktől, vagy egyedül élő anyától származik. És az arány valószínüleg növekedni fog. Hiszen 1980-ban a nem házas kapcsolatból származó születések aránya 7,1 \%, 1998-ban már 26,6 \% volt (Pongrácz, 2015), 2014-ben 47,6\% volt (Statisztikai Tükör, 2015). (Egyáltalán, arról, hogy a nem-házasság körülményeibe való beleszületés vezet-e nevelődési specifikumokhoz, nincs megbízható tudásunk.)

Ha a családszerkezet az iskolás évek alatt változik (testvér születése, szülő halála, válás, újraházasodás, kivándorlás, elköltözés - visszaköltözés) rányomhatja a bélyegét a gyerek viselkedésére, tanuláshoz való viszonyára stb. A statisztikai kimutatások szerint a gyerekek életét gyakran érzelmi válságba sodró válások száma nálunk is egyre nagyobb mértéket ölt. Az ezredforduló után évente 25000 válás, 2012-től némi csökkenés tapasztalható, igaz, hogy csökken a házasságban élő párok száma is. 2013-ban 20000 válást (Statisztikai Tükör, 2014) regisztráltak.

A hazai házasodási szokások (hasonlóan a nyugat-európai gyakorlathoz) az utóbbi évtizedben átalakulnak, konkrétan egyre idősebb korban házasodnak a férfiak és a nők. Pontosabban fogalmazva, egyre későbbi életkorokban egyre kevesebb esetben szánják el magukat házasságkötésre (Maksay, 2013). A szülők életkora a gyerek nevelődése szempontjából nem mellékes. A generációk közötti időbeli távolság növekedése hozzájárul az értékek, a szükségletek, a szokások, az ízlés területén való távolódáshoz.

Hasonló következményekhez vezet az a gyakori helyzet is, hogy fiatal anyák és idősebb (régebben inkább nagyapa korabeli) férfiak vállalkoznak közös gyermeknevelésre. Az ilyen családi struktúrákban a családi nevelés típusos ártalmaként gyakran jelenik meg a túlféltés, ami az iskolai társas helyzet elfogadását, az abba való beilleszkedést a gyerek számára meglehetősen nehézzé teheti.

A családszerkezet változása nemcsak az életmód, hanem mindig az érzelmi kapcsolatrendszer átalakulását is jelenti, amelyet a családtagok különböző előjellel és intenzitással élnek át. Ezeket a változásokat a gyerekek megélhetik veszteségként is, és természetesen ugyanilyen eséllyel megnyugvásként is, érzelmileg gazdagodva.

Azonban arra érdemes számítani, hogy az e változásokat megelőző, nem ritkán elhúzódó folyamatok lekötik, az iskolai tanulástól elterelik a gyermekek gondolkodását, figyelmét, gyakran feldúlják érzelmi életüket. A felnőttek életének olyan szegmenseibe nyernek nem ritkán betekintést, olyan jelenségekkel, folyamatokkal szembesülnek, amelyeket korábban a felnőttek titkoltak gyerekeik előtt. A gyermekek találkozása ezekkel az érettségi szintjüket meghaladó tapasztalatokkal, az ezekkel való értelmi, érzelmi birkózás elvonhatja figyelmüket az iskolai tennivalókról. Ennek következménye lehet az iskolában a motiválatlanságon, figyelmetlenségen kívül a feszültség levezetésére alkalmazott verbális vagy fizikai agresszió (gyakoribb) megjelenése is.

\section{A családok aktuális életciklusa}

A családok életciklusainak felismerése, leírása, az egyes szakaszokból való átmenet problémái, a normatív krízisek értelmezése a múlt század második felében jelentek meg a pszichológiai szakirodalomban. A dinamikus családpszichológia megalapítójának Hill és Rodgers tekinthetők, munkásságában Ericson is jelentős szerepet szán a családi életciklusok leírásának. 
Hill és Rodgers alapján a gyermekkel rendelkező családok életciklusai a következők:

- az újonnan házasodott pár,

- a csecsemős család (0-3 éves korig),

- a kisgyerekes család (3-6 éves korig),

- a serdülőkorú gyerekes család,

- a felnövekedett gyermeket kibocsátó család,

- a magukra maradt, aktív szülők,

- az inaktív, idős házaspár.

A normatív krízisek abból adódnak, hogy a változással, fejlődéssel új szükségletek jelennek meg, ennek következtében újfajta müködésre, új kapcsolatokra kerül sor, amelyek egyaránt vezetnek nyereségekhez, veszteségekhez, olykor müködési zavarokhoz, elakadásokhoz (Komlósi, 1997).

A családdal kapcsolatos változások miatt azt mondhatjuk, hogy nincs arra esély, hogy ezek a normatív családi krízisek a leírások szerint „szabályosan”, lineárisan követik egymást, hiszen két vagy több ember (sokszor változó) együttéléséröl van szó. A családi krízisek az egyéni krízisek egyidejű összegeződéséből adódnak. Inkább az tekinthető életszerűnek, hogy egy családban egyszerre, párhuzamosan több krízis állapot is kibontakozik. Például a serdülökori krízis fázisában élő fiatalnak testvére születik, s miközben az új gyerek öröme-gondja az életközépi krízisben levő az anyára hárul, az idősödő apa már a kapuzárási pánik rémével viaskodik. A nagyszülők időskori kríziseire így aztán kevés családi figyelem jut.

A normatív krízisek sajátos természete, hogy következményeit tekintve a család egészét, az együttélők mindegyikét érinti, a családtagokat összekötő kommunikációs, érzelmi kapcsolatrendszeren keresztül. Miközben természetesen mindenki a saját krízis állapotából is tovább akar lépni. És gyakran van olyan helyzet is, amikor a normatív krízisek mellé a családokban akcidentális krízisek is megjelennek, mint például valamelyik családtag kivándorlása vagy éppen visszatelepülése, válás, betegség, halál.

A családi krízisekből, a gyerek kríziseiből való továbblépés segítése csak olyan mértékben lehet a pedagógus feladata, hogy nem nehezíti a helyzetet. Megfelelö arányérzékkel rendelkezve például látja, hogy milyen jelentősége van egy diák életében apja elvesztésének vagy akár csak egy (rosszul sikerült) dolgozatnak. Ami a pedagógustól az ilyen helyzetekben elvárható: a pszichológiai tájékozottság, érzékenység, a krízis jeleire való felfigyelés, értő reagálás; az akcidentális krízisek okozta feszültségeken, pszichés elfordulásokon együttérzéssel való átsegítés, támogató kapcsolathoz való irányítás.

\section{A családok egészségi állapota}

A statisztikai adatok szerint a mai magyar társadalom egészségügyi helyzete romlik. A születéskor várható élettartam nálunk lényegesen alacsonyabb, mint az EU országoké. (A magyarországi átlag 74,23 év, az EU országok átlaga 79,31 év volt 2010-ben.) Ami az életminőséget illeti, a felnőtt lakosság életét végigkíséri a stressz. A depreszsziós tünetegyüttes a 45 évnél fiatalabb férfiak esetében 19\%-ban, a nőknél 22\%-ban van jelen. Érdemes felfigyelni arra, hogy a gyerekes fiatal nők körében a depresszió még gyakoribb, 24\% (Kopp és Skrabski, 2009) Az meg már szinte közhely, hogy a káros szenvedélyek tekintetében igencsak előkelő helyen szerepel az ország.

A családtagok fizikai állapotából, betegségéből adódó helyzete rányomhatja bélyegét a gyerek gondozottságára, kedélyére, gyakran lehet a háttere az elkalandozó figyelemnek, a fáradtságnak. Egy baleset következményeit, egy gondozásra szoruló beteg nagyszülővel kapcsolatos gondokat egy diák sem tudja az iskola kapun kívül hagyni. 
Sokkal nehezebb felderíteni a család mentális problémáit. Rainer Winkel (Winkel, 1981) a következő neurotikus családtípusokat írja le:

- Az „elszigetelő család”, amelyre az jellemző, hogy valamelyik tagját kizárja a családi kommunikációból, üzengetnek egymásnak. („Mondd meg a lányodnak...”)

- A „viaskodó család”, amelyre az jellemző, hogy a szülők egymással harcolnak, vetélkednek az egyetlen gyermek szeretetéért, vagy a másik gyerek szeretetéért is. (Gyakran alakul ez így válások esetén, miközben a gyermek mindkét szülö szeretetéért harcol.)

- Az „ambivalens család”, amelyre az jellemző, hogy a családtagok között szeretet és gyűlölet kapcsolatok egyaránt fennállnak, de a kapcsolatok nem kölcsönösek. Ezek a kapcsolatok egyensúlyi helyzetbe merevednek. Új tag megjelenése esetén (féltve a kialakult egyensúlyt) egységesen ellene fordulnak.

- A „kulisszacsalád”, amelyre az jellemző, hogy a családtagok egymás számára játszanak el olyan érzelmeket, szerepeket, amelyek nincsenek. Túlélési stratégiájuk a double-bind kapcsolat.

- A „körcsalád”, amelyre az jellemző, hogy mindenki szeret valakit a családban, de ő a szeretetet mástól kapja. Minden kapcsolatban van egy szerető és egy szeretett, amely kapcsolatban a fölérendeltség a szeretett személyre jellemző.

- Az „úr és szolga” családra az jellemző, hogy az alávetettségből a szolga helyzetben levő családtag továbbadja az őt ért gyötrést, vagy éppen lázad ellene, garantálva a belső összeütközéseket.

- A „gettócsaládra” az jellemző, hogy a családtagokat szorongással teli kapcsolatok füzik össze, a családot érő külső eseményeket fenyegetésként élik meg, bezárkóznak.

Az egyes típusokat Winkel konkrét esetekkel szemlélteti, s egyben jelzi, hogy ez korántsem zárt, végső felsorolás, a rendelkezésére álló esetek tipizálását végezte csak el. Kiemeli, hogy a család működése mögött mindig az egyének élettörténete áll, a családi neurózisok gyökereit a családtagok életeseményeiben lehet/kell keresni.

A hazai szakirodalom jóval differenciáltabb, szakszerübb, modernebb, ugyanakkor tapintatosabb megközelítést sugall a „sérülékeny család” kifejezéssel. Az e témában pedagógusok számra készített kézikönyv a családot önszabályzó rendszernek tekinti, s nemcsak keresi a mentális problémák felismerését segítő tüneteket, következményeket, hanem a gyógyítás lehetőségeit is, különös tekintettel a játékra ( $F$. Lassú, 2011; Kolosai, 2011).

A kézikönyv szembesíti az olvasót azzal, hogy a társadalom romló fizikai-mentális állapota az iskoláskorú népességre is rányomja a bélyegét. A felnőttek problémái a gyerekekkel való bánásmódban is megjelennek, ezek közül az elhanyagoláson túl a verbális, a fizikai, az érzelmi és a szexuális bántalmazást tartjuk számon. Magyarország a huszonhét legfejlettebb OECD ország közül gyermekbántalmazás terén hátulról a negyedik a rangsorban. Egy feltárt esetre huszonöt feltáratlan jut. Ennek a tüneteit észlelve azonnal lépni kell a gyermekvédelmi jelzőrendszeren keresztül. A mentális megsegítés már nem tartozik a pedagógus hatáskörébe, de a segítők értesítése, szükség esetén a segítők javaslatainak támogatása, felerősítése, kötelező feladata (Hajdú, 2011).

\section{A családok társadalmi, gazdasági helyzete}

A családok társadalmi, gazdasági helyzete az iskolából tekintve a családok munkavállalási és anyagi lehetőségeiben ragadható meg. Szegénység, gazdaság - minden társadalom gondja. Szépirodalmi művek sora vall arról például, hogy mit jelentett Magyarországon valamikor iskolában szegény gyereknek lenni (vö. például Móra Ferenc múvei). 
Az utóbbi évtizedekben a magyar társadalomban ismét megismert (nagymértékủ) munkanélküliség, az ennek nyomán kialakuló gyermekszegénység feltétlenül rontja az iskola hatékonyságának esélyeit. Az UNICEF 29 fejlett országra kiterjedő vizsgálata szerint a magyar gyermekek (1-16 éves korig) 20,6\%-a súlyosan deprivált, azaz súlyosan nélkülöző. Ez az érték még rosszabb az egyszülős háztartásokban (47,3\%) és a munkanélküli háztartásokban (64,9\%) (UNICEF Report Card 10).

A gyakran éhes, személyes (fizikai és érzelmi) szükségleteiben hiányt szenvedő, a felnőttek reménytelen életét saját lehangoló perspektívájának tekintő gyermekek, fiatalok az iskola funkcióinak hivatalosan elfogadott koncepciójától, az iskola hagyományos működésétől nagyon távol vannak. A szegény települések egyre gyengébb teljesítménymérési eredményei mögött - ebben biztosak lehetünk - nem csak pedagógiai okok vannak. Pedagógiai eszközökkel az iskola céljai, elvárásai és a napi életmód közötti távolság egyre nehezebben, világosan szólva, nem is leküzdhető.

Ugyanakkor kialakult, alakul a társadalomnak egy olyan rétege is, amely anyagilag, lehetőségeit illetően lényegesen jobb helyzetben van, mint akár a pedagógusok zöme. A diákok egy kis része szüleivel utazik, külföldön nyaral, világot lát, a legmodernebb informatikai eszközökkel rendelkezik, amelyek segítségével minden jót és rosszat megtanulhat. Illúzió lenne azonban azt hinni, hogy a pedagógusok számára ezek az együttmüködés szempontjából vágyott családok. Gazdagság - szegénység, ez mindig így volt. De korábban az anyagi szerénységet a társadalom szemében pótolta a műveltségbeli gazdagság, a pedagógus professzió magasra értékelése. $A$ „tisztes szegénység” becsülete. A mai „új gazdagok” életvitele, szemléletmódja gyakran távol esik az iskola, a pedagógusok elképzeléseitöl. Az iskola és a családok közötti feszültségek, távolságok nagyon gyakran éppen olyan nehezen leküzdhetők, mint a szegénység esetében. Különösen, ha ezt a helyzetet még színezi a rendkívül jómódúak pökhendisége, a pedagógus kisebbrendűségi érzése, irigysége, hiszen ez utóbbiak is elhomályosíthatják a pedagógiai tisztánlátást.

\section{A család valláshoz való kapcsolódása}

Magyarországon vallásszabadság van. A szociológiai kutatások szerint a fiatalok egyre kevésbé vallásosak, a vallásosakra pedig gyakran jellemző a vallási individualizáció (a nem egyházi tanítások követése). A jelenlegi fiatalok szülei a 60-as, 70-es években, a vallás háttérbe szorulásának idejében szocializálódtak, ezért gyermekeiknek is csak kismértékben biztosítottak vallásos nevelést. A fiatal szülőknek a rendszerváltás után a valódi vallásosság megélése mellett lehetőségük nyílt a vallási kulisszák divatból, esetleg karrierizmusból való követésére is, ám mindez a gyermekek vallásos nevelése szempontjából érthetően nem jelentkezik pozitívumként. Ez magyarázhatja, hogy a 2000-ben megkérdezett fiatalok (15-29 évesek) 38\%-a nyilatkozott úgy, hogy a családban vallásos nevelésben részesült, 2012-ben ez az alacsony érték is $27 \%$-ra csökkent. Egy friss kutatási eredmény szerint a szülök az iskolától nem is várják el a vallásos nevelést (Hunyady és $M$. Nádasi, 2014). Ami inkább meglepő lehet, az egyházi iskolák csak kismértékben tudják pótolni a család vallásos nevelését (Rosta, 2013) .

Állami iskolában tanító pedagógus számára a diákok bármilyen valláshoz való tartozása csak akkor jelenthet igazán kérdést, ha olyan feladatok, események lennének aktuálisak, amelyeket tilt a tanuló vallása. A pedagógus számára egy feladat adódik: a vallási tiltások tudomásulvétele, és olyan körülmények megteremtése, hogy ez ne vezessen a gyerek kirekesztéséhez. Fontos ezért, hogy a pedagógus megismerje a vallások napi életet befolyásoló elvárásait, s képes legyen ezeket előítéletek nélkül akceptálni. 


\section{A család nemzetiségi, etnikai hovatartozása}

Színes és egyre színesebb a kép abban a tekintetben, hogy az egyes intézményekben milyen vállalt és nem vállalt nemzetiségű, etnikai hovatartozással rendelkező diákok tanulnak együtt. A pedagógusok számára ez a körülmény azért lehet fontos, mert a nemzetiségi, etnikai hovatartozás mind a korábban említett értékeket, mind a családi nevelési szokásokat, a valláshoz való tartozást befolyásolhatja.

Magyarországon legnagyobb szakirodalmi háttere a romák családi nevelésével kapcsolatos tudásnak van, hiszen a népességen belül a legnagyobb etnikumot legrégebben ők képviselik. Ma már elmondható, hogy azon a korszakon túl vagyunk, miszerint „a cigányok nem nevelik a gyerekeiket”. Ma már - szerencsére - kezd közhely lenni, hogy nevelik, csak mások a nevelési szokásaik, hagyományaik, körülményeik. Az ismeretek terén bekövetkezett változás természetesen csak akkor vezet a cigánygyerekekkel hatékony bánásmódhoz, ha attitüdváltozás is kíséri (Forray és Hegedűs, 2003).

A jelenlegi körülmények között a családok nemzetiségi hovatartozásából, nevelési szokásokból adódó pedagógiai kérdések megsokasodhatnak. Keveset tudunk a Magyarországra bevándorlók gyerekeivel való foglalkozásról. Pedig már 2014-ben, az engedéllyel, huzamosan itt tartózkodó külföldi bevándorlók száma 138000 volt. A lakosság 1,4\%-a. (A bevándorlók 74\%-a Európából, 19\%-a Ázsiából, 3\%-a Afrikából és az amerikai kontinensröl érkezett.) (Statisztikai Tükör, 2014).

A különböző kultúrákhoz tartozó családok nevelési értékei, szokásai nagymértékben különbözhetnek egymástól, befolyásolhatják a pedagógiai intézményekben szükségesnek tartott eljárásokat is. A pedagógusok más kultúrák, más kultúrák családi nevelési szokásai stb. iránti nyitottsága, az ebböl elvonható következtetések figyelembevétele az egyes gyerekekkel, gyerek csoportokkal való foglalkozásban meghatározó lehet. Másrészt a gyerekek különböző nemzetiségekhez való tartozása segítheti az iskolák multikulturális nevelésének élményszerü megvalósítását.

Az iskolába járó, több nemzetiséghez tartozó tanulókkal való foglalkozás a korábbi években nálunk nem kapott nagy hangsúlyt. Biztos, hogy a nemzetközi pedagógiai gyakorlat megismerése ezen a területen segítséget adhat. Az osztrák, a német, a holland közoktatás már évtizedek óta halmozza jó eredménnyel ezen a téren a tapasztalatokat. De a hazai intézményeknek is van már tapasztalatuk, hiszen a bevándorlók gyerekei számára évek óta biztosítják az óvodai, az iskolai nevelést. A hazai intézmények egymástól való tanulása, a külföldi tapasztalatok megismerése akár azonnali segítséget nyújthat, hiszen jelenleg több erről a területröl a gyakorlati tudás, mint a tudományos kutatás eredményeként megfogalmazott.

\section{Hétköznapi pedagógiai elméletek a családi nevelés hátterében}

A családokban a felnőttek természetesnek tartják nevelő szerepüket, feladatukat. Teszik mindezt annak ellenére, hogy nincs ilyen tekintetben képzettségük. Saját közvetlen és közvetett tapasztalataik, a szépirodalom, az ismeretterjesztő irodalom, az internetben olvasott írások alapján kialakuló elképzelés a felnőtt szerepéről a gyermek nevelésében befolyásolja, hogy a családok nevelése hogyan alakul ( $M$. Nádasi, 1999).

Ez is olyan tény, amelyik a nevelés történetével egyidős. Csak a nem-professzionális tudásnak, a hétköznapi pedagógiai elméleteknek a tartalma változik. A neveléstörténeti kutatásoknak az a vonulata, amely a társadalom által konstruált gyermekképpel foglalkozik, meggyőzően mutatja be, hogy a korábbi évszázadok gyermekkel kapcsolatos nézetei változtak abban a tekintetben, hogy a gyermeket ördöginek, angyalinak, 
a korlátlan lehetőségek hordozójának tekintették-e. Ezek a nézetek nem váltották egymást, hanem párhuzamosan, történeti korokon átívelve együtt éltek. A gyermekröl való tudás halmozódását illetően új fordulatot jelentettek a fejlődés pszichológia, a humanisztikus pszichológia felismerései. A nagy fordulatot az a 20. századi megközelítés jelentette, amely továbblépett azon a normatív szemléletmódon, amely a gyermekkort, mint a kívánatos felnőttkor elérésének szakaszát értelmezte, s felhívta a figyelmet a gyermekkor önértékére. Ezt a szempontot még sem a pszichológia, sem a pedagógia nem dolgozta fel alaposan, ugyanakkor az elmúlt ötven évben a fogyasztó társadalom már mind nézeteiben, mind gyakorlatában kitermelte a fogyasztó gyermekképet (akiknek gondolatvilágában a reklámok, a média hatására a felnőttek egyáltalán nem elérendő minták, hanem csak zavaró elemek, legyenek azok a szülők vagy a pedagógusok), megteremtve ezzel az „elsietetett gyermekkor” jelenség- és gondolatkörét (Golnhofer és Szabolcs, 2006; Vajda, 2009).

Tudjuk, hogy a hétköznapi (laikus) pedagógiai tudás hagyományozódik, nehezen változik, teljesen természetes, hogy egyszerre élhetnek a történetileg kialakult különböző gyermekfelfogások, és az ezekhez illőnek vélt, vagy ezekről mit sem sejtő hétköznapi pedagógiai elméletek a családi nevelés alapjaiként. Napi tapasztalat is lehet, hogy egy családban eltérő vélekedés alakul ki a gyerekekről a testvérsorban elfoglalt helyük, képességeik, külsejük stb. alapján. Ezek a nézetek alapvetően befolyásolják a gyerekekkel való családi bánásmódot, hiszen nem mindegy, hogy pl. a gyerekben a megtestesült rosszat látják, akinek akaratát, törekvéseit meg kell törni, vagy a megtestesült jóságot, akinek teljes körü kényeztetés, elismerés jár stb.

A családokban a gyerekekről, a nevelhetőségükről, az alkalmazható nevelési eljárásokról kialakult véleményről, az ezek alapján alkalmazott nevelési módszerekről folyamatos, általában latens, kritikus esetben sokszor viharos egyeztetés zajlik. Hiszen egyben biztosak lehetünk: hétköznapi pedagógiai elméleteik tekintetében a családtagok között a legnagyobb harmónia esetén sincs teljes egybeesés, hiszen a hétköznapi pedagógiai elmélet legfontosabb alapja mindenki esetében a közvetlenül, személyesen szerzett pedagógiai tapasztalat. Márpedig ez mindenki esetében más. A pedagógus jó esetben ennek az egyeztetési folyamatnak az eredményével találkozik, de a családtagokkal való beszélgetés esetén a különbségek élesen is kirajzolódhatnak.

Érdemes a családból érkező nézetekre figyelni. Ha nem is professzonálisak - a gyerekkel kapcsolatban más közegben szerzett számtalan tapasztalaton, és az esetek többségében a gyerek iránt érzett felelősségérzeten alapulnak.

A szülökkel való együttmüködést talán segíti, ha meggondoljuk: a gyereket nevelő felnőttek sem mindig találják gyerekeikhez a megfelelő nevelési módszereket. A változó világ ebben a tekintetben olykor őket is eszköztelenné teszi. Része ez annak a folyamatnak, aminek a következményeit gyakran tapasztaljuk. A múlt század második felében a nagymértékủ életmódváltozás (a nők munkába állása, az apák ingázása, az iskoláskorú, továbbtanulni szándékozó gyermekek kollégiumba kerülése) szakadozottá tette a generációk között a tapasztalatok, a napi gyakorlat átadását, átvételét. Gondolhatunk arra, hogy a jelenlegi gyermekek nagyszülei pedagógiai nézeteiket megalapozó tapasztalataikat nagyon gyakran külsőségeiben is apadominanciájú, korlátozó családban szerezték, az elmúlt fél évszázadban csendben lezajló szexuális forradalom következményeivel saját életükben csak rossz lelkiismerettel kerültek kapcsolatba, hogy életükben a szülők elmaradt felvilágosító szerepét az internet nem pótolta még. Gyermekeik, a mai fiatal szülők, saját neveltetésük során éppen az előzőek miatt sok bizonytalanságot, következetlenséget éltek át, alig van tapasztalatuk 
arról, hogy milyen eszközei vannak a nem-tekintélyelvű nevelésnek (amit általában nagyon fontosnak tartanának), de a szülői tekintélyt mégsem romboló, hanem kölcsönös szeretetre, tiszteletre alapozó kapcsolat megteremtésének. A pedagógustól érkező szakmailag értékes információk egy ilyen helyzetben felértékelődnek. Mint ahogy a könyvkiadók is egyértelmü sikerként számolnak be a nevelési tanácsadás témájában a szülők számára kiadott könyveik keresettségéről.

\section{A családdal kapcsolatos változások hatása a gyerekekre és a velük való pedagógiai munkára}

A fentiekben átgondolt, családokra jellemző sajátosságok a valóságban komplexen, s mint ahogy azt már jeleztük, más hatásrendszerekkel együtt érvényesülnek. Ezért nem lenne járható út az, ha az egyes sajátosságokból próbálnánk levezetni a pedagógiai tennivalókat. Hiszen ugyanazok mögött a tünetek mögött (pl. figyelmetlenség, agresszióra való készség, nagyfokú érdeklődés) különböző, a családból is eredeztethető okok, azok együttese húzódhat meg. Amit valamennyi sajátosság együttesen sugall: a megváltozott, az egyes pedagógusok számára szokatlan, nem ritkán zavaró családi körülmények, nézetek, szokások figyelembevételére szükség van. Hogy mi a célszerü, mi az eredményes, az a konkrét helyzet függvénye.

De honnan lehet megtudni, hogy a diákok pozitív vagy negatív tüneteket mutató viselkedése mögött valamilyen módon a család is szerepet játszik? Szükséges arra gondolni, hogy a figyelmetlenség, a motiválatlanság mögött ugyanúgy lehet az első szerelem boldogító izgalma, mint az élet (esetleg más felnőttek, esetleg éppen a szülök vagy éppen más tanárok) által okozott sérelmek. A személyiségi jogokra tekintettel mindezekröl a pedagógusok hivatalosan nem értesülnek. Régi naplókat, bizonyítványokat, dokumentumokat lapozgatva elcsodálkozhatunk azon is, hogy e tekintetben is mekkorát változott a világ. A bejegyzett anyanyelv, vallás, a vallás változtatás, mindkét szülő konkrét foglalkozása, a szegénységi bizonyítvány - a pedagógus hivatalos alapinformációi közé tartoztak még az elmúlt évszázadban is. A jelenlegi bejegyzések nem a tanulók konkrét családi körülményekből, hanem oktathatóságából, nevelhetöségéből indulnak ki.

Jelenleg a családi háttér pozitívumai, negatívumai csak pedagógiai eszközökkel - beszélgetések, megfigyelések - deríthetők fel. Persze ennek jó alkalmai lehetnek a családlátogatások, a szülői értekezletek, a fogadó órák és egyéb alternatív együttmüködési formák is. (A gyerekek ezzel kapcsolatos spontán közléseire még legfeljebb a kisgyermekkor végéig számíthatunk.)

A pedagógiai támogatás a tapintatos egyéni bánásmódban a leghatékonyabb. Ezt akkor is tudnunk kell, s ez akkor is így van, ha kevés az egy gyerekre hivatalosan jutó idő, ha a pedagógus maga is krízishelyzettel küzd.

Valódi együttmüködést várhat el a pedagógus a szülőtől, ha tud azért tenni, hogy a szülők pedagógiai, pszichológiai tudatossága fejlődjön. Pedagógusnak és szülőnek is érdemes azt felismerni, hogy rövidre szabott találkozásaikon ne csak a gyermekekről legyen szó, hanem arról a kontextusról is, amelyet a család jelent. (Nagyon jellemző, hogy ha a szülői értekezlet témája például a serdülőkor, de hogy a serdülőkor átélésének minősége függ a családi háttértől is, alig esik szó.)

Egy biztos: a családok által képviselt értékek, a családok müködése az iskola számára adottság. Az együttműködés érthető, tapasztalattal is, elméletileg is alátámasztható elméleti kívánalom. Az együttmüködés kulcsa a pedagógus kezében van. Bár előfordulhat, hogy a kulcs nem illik a zárba, akár a kulcs, akár a zár miatt. 


\section{Felhasznált irodalom}

Bábosik István, Brunner, E. J., Groissen, C., M. Nádasi M., Nachtigal, Ch. és Stauche, H. (2005): Attitüdvizsgálatok a családi belsö kapcsolatok, a családi tevékenység és kapcsolatrendszer alakulásáról. Kézirat, Budapest.

Bertram, H. (1997): Getrennt wohnen - solidarisch leben. Die „multilokale Mehrgenerationen Familien” In: Krappmann, L. \& Lepenies (Hg.): Alt un Jung. Spannung un Solidaritat zwischen den Generationen. Campus, Frankfurt am Main, 79-84.

Boreczky Ágnes (2004): A szimbolikus család. Gondolat Kiadó, Budapest.

Bönisch, L. és Lenz, K. (1997, szerk.): Familien. Eine interdisziplinare Einführung. Juventa, München.

F. Lassú Zsuzsa (2011, szerk.): Gyermekek mentálisan sérülékeny családokban. Kézikönyv pedagógusoknak. ELTE Eötvös Kiadó, Budapest.

Forray R. Katalin és Hegedűs T. András (2003): Cigányok, iskola, oktatáspolitika. Új Mandátum, Budapest.

Golnhofer Erzsébet és Szabolcs Éva (2006): A gyermekkor narratívái. In: Kelemen Elemér és Falus Iván (szerk.): Tanulmányok a neveléstudomány köréből 2005. Müszaki Kiadó, Budapest, 135-145.

Hajdú Krisztina (2011): A gyermekvédelmi rendszer müködése mentálisan sérülékeny szülök gyermekeinek támogatása során. In: F. Lassú Zsuzsa (szerk.): Gyermekek mentálisan sérülékeny családokban. Kézikönyv pedagógusoknak. ELTE Eötvös Kiadó, Budapest, 173-206.

Hankiss Elemér (1983): Társadalmi csapdák. Diagnózisok. Magvető Kiadó, Budapest.

Hunyady Györgyné és M. Nádasi Mária (2014): Szülök és gyerekeik iskolaképe - 2012. In: Hunyady Györgyné és M. Nádasi Mária (szerk.): Az iskolakép változatai és változásai. ELTE Eötvös Kiadó, Budapest, 95-112.

Kaufmann, F. X. (1995): Zukunft der Familie in vereinten Deutschland. Gesellschaftliche und politische Bedingungen. München.

Kolosai Nedda (2011): Komolyan venni a játékot - Pedagógiai segítő munka mentálisan sérülékeny szülők gyermekeivel és családjával. In: F. Lassú Zsuzsa (2011, szerk.): Gyermekek mentálisan sérülékeny családokban. Kézikönyv pedagógusoknak. ELTE Eötvös Kiadó, Budapest, 121-148.

Komlósi Piroska (1997): A család támogató és károsító hatásai a családtagok lelki egészségére. In: Gerevich József (szerk.): A közösségi mentálhigiéné. Animula Kiadó, Budapest, 13-34.

Kopp Mária és Skrabski Árpád (2009): Nők és férfiak egészségi állapota Magyarországon. In: Nagy Ildikó és Pongrácz Tiborné (szerk.): Szerepváltozások. Jelentés a nők és férfiak helyzetéről 2009. TÁRKI - Szociális és Munkaügyi Minisztérium, Budapest, 117-136.

URL: http://www.tarsadalomkutatas.hu/kkk.php?TPUBL-A-882/publikaciok/tpubl_a_882. pdf (utolsó megtekintés: 2015. október 30.)

Lénárd András (2009): A laikus pedagógiai nézetek megjelenése az interneten. Iskolakultúra, 19. 1-2. sz, Melléklet, 3-11.

Makay Zsuzsanna (2013): Párkapcsolati magatartás és családalapítás fiatalok körében. In: Székely Levente (szerk.): Magyar Ifjúság 2012. Tanulmánykötet. Magyar Közlöny Lap- és Könyvkiadó, Budapest, 53-89.

Nagy Ádám és Trencsényi László (2012): Szocializációs közegek a változó társadalomban. A nevelés esélyei: család, iskola, szabadidő, média. ISZT Alapítvány, Budapest.

Pongrácz Tiborné (2011, szerk.): A családi értékek és a demográfiai magatartás változása. KSH Népességtudományi Kutató Intézet, Budapest.

Pongrácz Tiborné (1999): „Gyermekvállalás házasság nélkül” In: Pongrácz Tiborné és Tóth István György (szerk.): Szerepváltozások. Jelentés a nők és férfiak helyzetéröl. TÁRKI, Budapest, 173-189.

Rosta Gergely (2013): Hit és vallásgyakorlat. In: Székely Levente (szerk.): Magyar Ifjúság 2012. Tanulmánykötet, Magyar Közlöny Lap- és Könyvkiadó, Budapest, 316-331.

Statisztikai Tükör 2014. 28. Központi Statisztikai Hivatal, Budapest 
Statisztikai Tükör 2015.március

URL: http://www.ksh.hu/docs/hun/xftp/idoszaki/nepmozg/nepmoz14.pdf

UNICEF REPORT

URL: 10 http://www.unicef-irc.org/media-centre/press-kit/Report-Card-10/ (utolsó megtekintés: 2015. október 30.)

Vajda Zsuzsanna (2009): Siettetett gyerekek. Iskolakultúra, 19. 9. sz., 3-14.

Winkel, R. (1981): Pedagógiai pszichiátria szülők, pedagógusok és nevelök számára. Tankönyvkiadó, Budapest. 